\title{
Impact of IS Strategy and Technological Innovation Strategic Alignment on Firm Performance
}

\author{
Asare Yaw Obeng \\ Kumasi Polytechnic, Kumasi, Ghana; University of South Africa, South Africa \\ E-mail: yawo.asare@kpoly.edu.gh \\ Prof. Peter L Mkhize (PhD) \\ University of South Africa, South Africa \\ E-mail: mkhizpl@unisa.ac.za
}

Received: 10 September 2016; Accepted: 30 December 2016; Published: 08 August 2017

\begin{abstract}
The alignment between information systems strategy and business strategy as an important driver of competitiveness has predominantly been assessed through quantitative methods without exploring in detail factors that influence strategic alignment and their implications for perceived business performance. Most IS-business strategic alignment studies dominantly focus on entire business and IS strategies resulting in many findings that are too general and inconclusive. This study aims at assessing strategic alignment factors, their interrelationships, and how they influence the IS-business alignment and its consequential effect on the performance of six universal banks in Ghana. The study followed the systematic procedure of grounded theory design and adopted qualitative dominant crossover mixed analysis. The findings of the study indicate strategic alignment between information systems strategy and technological innovation impacts positively on the performance of a firm where IT utilization complements resources and capabilities.
\end{abstract}

Index Terms-Firm performance, information systems strategy, strategic alignment factors, technological innovation.

\section{INTRODUCTION}

The Ghanaian banking industry is fairly saturated comprising 31 universal banks, 140 rural and community banks, 576 microfinance institutions, and 65 non-banking financial institutions including finance houses, savings and loans, and leasing and mortgage firms [1]. This has further exacerbated the intensity of competition in the industry culminated with government policies, globalization, culture diversity, social renewal, products and/or services similarities, poor telecommunication infrastructure, and advancements in technology. The universal banks among these financial firms are challenged to search for sources of sustainability by exploiting technology to alter their mode of operations, lower costs, support their business strategies or create new strategic options, and increase performance [2].

In the global competitive environment, accelerating innovation enables banks to reduce costs and risks, counter market forces, improve inefficiencies and spark growth, maintain global banking standards [3], offer individualized, short-lived, and information-rich niche products and services to customers, create competitive advantage and improve performance [4]. Products uniqueness and activities that are related to marketing, customers, people management, innovation project culture, technological orientation, and financial resources must be captured in the innovation strategies of banks [5].

In the business environment that is becoming more complex and uncertain, firms are making significant investments in information systems to improve information processing, communications and collaboration [6], align business strategies and enable innovative functional operations [7], facilitate costs cut and products and/or services differentiation [4], and creates competitive advantage throughout the value chain [8]. According to [9], "IT has become an important aspect of everyday business and potentially a key element in competitive positioning." Financial institutions globally are using IT as a critical strategic organizational resource to integrate functional areas within an organization [10] and pursue innovative strategies to promote growth, improve performance, and increase market share.

Individually, IS and innovation could have a positive impact on the performance of a firm. Information systems serving as an important ingredient of innovation development facilitate much of the innovation that has been embraced as business practice [11]. There is a need to achieve strategic fit where the alignment between IS and innovation determines IS effectiveness and significantly enhances the performance of a firm [12]. Most of these strategic alignment studies conducted focused generally on IS and business strategies, and whether - and how - strategic alignment creates value 
[13] is inadequately clarified in the literature [15]. Thus, how the alignment or the lack of it between information systems strategy and technological innovation impact on the performance of a firm will focus mainly on information systems support for technological innovation.

The paper is organized as follows: section II gives the overview of the past related work in the areas of firm performance, technological innovation, and the enabling role and strategic value of information systems to organizations. Section III describes research methodology for data collection, while section IV presents integrative analytical technique focusing on a qualitative dominant crossover mixed analysis and findings of the analysis. Discussion and concluding remarks of the research findings among the six (6) Ghanaian universal banks are covered in section VI.

\section{RELATED WORK}

Over the past two decades, the strategic value of information systems to organizations has been a major concern for many IS practitioners making IS scholars conducting numerous studies in this domain [15]; [16]. Organizations are effectively pursuing innovation through IS to address business challenges that continuously require organizations to adapt their business processes to changing market environment and customers' preferences. Business challenges are the profile of strategic assets and capabilities relative to the competitive environment of an organization [17]. These can impact the performance of a firm (especially profit potential) and must be assessed to determine the position of a firm in an industry [18].

\section{A. Firm Performance}

The need to reduce non-performing and toxic assets, cut operational costs, improve corporate governance, enhance customer-centric initiatives, assess returns and risk exposure, and meet organizational performance goals are the compelling management of financial institutions to adopt new practices and technologies [19]. The complexity of modern business environment requires a robust performance measurement and complex systems which are sufficient to cover all areas of an organization and its surroundings [5]. Organizational strategies are translated to results [20] and managers are provided with feedback on the progress of organizational goals [21] through performance measurement. [22] state, "A performance measure can be defined as a metric used to quantify the efficiency and/or effectiveness of action" (p.80). [23] and [24] suggest the need for a multidimensional measures covering both objective (financial or accounting measures like profits, sales revenue, operating income, gross margin, returns on assets, etc.) and subjective (non-financial measures including customer satisfaction, market share, employee turnover, people productivity rate, time to market, innovation rate, flexibility, process quality, productivity rate, and product/service quality - [25] measures. They are of the view that the traditional financial performance measures show misleading signals for continuous improvement, while the non-financial measures focus on future performance [21].

\section{B. Technological Innovation}

The banking processes in the 21 st century are being radically transformed through technology. Banks globally are continuously using better technologies to meet the challenges and opportunities in the dynamic environment they operate [26]. Technology solution can support sustainability strategy initiatives of banks by enabling them to develop innovative products and processes [27].

According to the OECD, innovation is the outcome of a range of complementary intangible assets including R\&D, software, human capital, new organizational structures, and collaborative networks that leads to new or significantly improved products, processes or methods that impact an organization, industry and/or an entire ecosystem of networks [28]; [29]. The [28] identifies product, process, marketing, and organizational as the four different types of innovation. Innovation efforts that focus on processes, products or services are classified as technical [30]. [31] regards technological innovation and creative destruction as the basis of competitive advantage for they critically influence market dynamics and competition. Innovation is critical to achieving operational efficiency and raising service quality [32]; reduces costs and risks, and improves performance [3]; and a vehicle of economic growth and competitive differentiation [33].

In this study, product and process innovation are both understood within the context of how IT enables the introduction of new or significantly improved products or services and the implementation of a new or significantly improved method of production or method of delivering a service. In the Ghanaian banking sector, banks are leveraging on the advancements in information technology to develop new or significantly improved products and/or services [34] to provide strategic services that are tailored to the unique requirements of their clients in a timely manner [35].

\section{i. Effects of Innovation on Firm Performance}

In the literature, innovation leads to organizational effectiveness, long-term survival [36], gaining a competitive edge and improving performance [37]. Most empirical studies provide positive evidence of the relationship between innovation and firm performance [38] with other studies indicating neutral or negative impact [39]. Increased in ideas and innovative R\&D capabilities [40], and innovation speed to launch new products with lower times and costs [41] contribute effectively to improving the performance of a firm. Adopting a specific innovation type influences firm performance [42]. For instance, product innovation resulted in superior financial returns [43] and process innovations positively impact firm performance [44]. For other researchers, combining several innovation types positively affects the performance of a firm [38]; [45] especially in the banking industry [3]. [46] states that 
"organizational performance may depend more on the congruency between innovations of different types than on each type alone" (p. 582). Technological innovation results in financial improvements that enhance economic growth [47]. In the banking industry, business transformation for growth and sustainability are critical, hence management must understand the innovationperformance contributory relationships.

\section{Enabling Role of Information Technology}

The constant advancement and effective utilization of IT to facilitate different streams of innovations, greater digitization, and efficient operations has resulted in the transformation of many business strategies [48]; [49]. Some organizations have achieved a sustainable competitive advantage over their competitors through IT [50]. However, IT system cannot deliver competitive advantage on its own unless it is strategically used to achieve business goals [51]. In the competitive global market, many organizations strategically interlink their IT and business strategies to achieve and or sustain competitive advantage [52]; improve productivity, performance, and core business processes [53] [54]; and ensure organizational strategies adapt harmoniously [53]. The contribution of IT to business performance has been studied from strategy as positioning perspective (marketdriven perspective) where the market power imperative considers industry structure as the primary cause of strategy and performance [55]; and a resource-based theory perspective that conceptualizes the enterprise as a 'bundle of unique resources' to define the essence of strategy and sustaining competitive advantage [56] [57].

\section{i. Information System Strategy}

In business strategy analysis, the acknowledgement that business and IS equally drive one another [58] and the contention that IS strategy can support and as well lead business strategy [59] require examining the IS strategy independently. The role of IT to facilitate business processes should be carefully defined and focus properly on business objectives, strategies, and tactics [60]. Information systems are considered a critical strategic organizational resource [51]; [61] and an essential enabler of business growth and economic development [62]. Firms are making significant investments in information systems to manage customer relationships and enable innovative functional operations [59]; [7]; bridge the gap in global development [63]; integrating functional areas to improve intra and interorganizational communications, collaborations, and operational efficiencies [10] among others. According to [64] and [51], the primary operational processes and information management activities that are crucial to the survival of an organization are defined through IT strategy.

IT strategy should include strategies that define the degree of data standardization across the organization, accountability for data quality [64], inventory of applications including hardware and software resources, infrastructure capabilities, IT staffing and governance, and the way an organization strategically views IT [51]. IT strategy enables organisations to support planned change in future directions and resources [51]. Since IT capability is an organization's ability to mobilize and deploy IS resources to complement other organizational resources and capabilities [65], IS researchers can adopt the resource-based theory of a firm to examine the competitive advantage derived from IT capabilities that are valuable, rare, and inimitable [66].

Conceptually, IS strategies differ in terms of their contextual elements [15]. IS strategy mainly focuses on the use of IS to support business strategy, IS strategy serving as the master plan of IS function, and IS strategy as the shared view of the IS role in an organization [15]. In business-centric, IS strategy is derived from a business strategy with the focus of using IS to support business strategy. With this conception, IS strategy cannot stand on its own or would not even exist if an organization does not have a clearly defined business strategy to support or intends to obtain a competitive advantage through IS. [58] and [67] suggest that IS strategy must be integrated with business strategy and as well drive it.

The IS strategy as the master plan of the IS function is $I S$-centric and focuses on the effective and efficient use of IS functionalities [15]. As a plan [68] it identifies and efficiently allocates the needed IS assets, structure, financial resources, and technologies. IS and business strategies need to be developed concurrently making this conception beneficial to an organization that does not have a formal business strategy or does not seek to achieve a competitive advantage using IS [69]. However, certain functional decisions made in isolation might not fall in line with the main organizational goal of improving the performance of a firm [70].

The conception of IS strategy as the shared view of the IS role in an organization is organization-centric and bridges the business strategy-driven and IS functiondriven conceptions [15]. This is an organizational perspective [68] [71] that directs current and future ISrelated business decisions and activities. The role of IS reflects the social dimension of IS strategic alignment [67] rather than the intellectual dimension since there is shared understanding between the business and IS practitioners that provide the highest potential to provide the most appropriate lens in extending future work within the IS strategy domain [15]. However, the top-down nature of this perspective does not allow strategic information systems to evolve from bottom-up direction to capture the deeply rooted firm-specific organizational culture that is difficult to imitate [72].

The intent to pursue innovation through IS provide another angle for categorizing IS strategy as IS innovators, IS conservatives or an undefined [15]. Organizations should maintain some degree of balance between explorative and exploitative IS-related actions to derive higher levels of performance [73] and also formulate an explicit or implicit IS strategy [15]. For efficient utilization and maximum benefit of the strategic value of information systems, some leading organizations are now seeking the means to build digital business 
platforms as a future proof of strategic move [74]. This is consistent with the view of [15] that most organizations pursue innovation through IS as part of their IS strategy initiatives. Successful strategy implementation depends on strategic fit where IS-business strategic alignment is in consistent with key business challenges they address.

\section{ii. IS Support for Technological Innovation}

Business strategy as a function of competition, positioning, capabilities [75], and a management analytical tool requires a strong management commitment in its formulation and execution [6]. The implicit or explicit business model that an organisation employs to support its business strategy and contributes to the delivering or capturing of innovation value is essential for technological innovation to succeed commercially [76]. As part of their strategic role, management purposely formulates an innovative strategy to address the uniqueness of their products, activities related to marketing and customers, people management, innovation project culture, technological orientation, and financial resources [5].

In an environment perceived to be of intensified competition such as the Ghanaian banking industry requires increased IT support for strategy [77] to contribute to innovation and growth [29]. In this study, IS support for strategy is specifically the alignment between IS and technological innovation (how IS support technological innovation as a business strategy). Innovation efforts depend much on information systems for practicality [78]. In literature, there are several streams of the role of information systems and technology in supporting innovation including business process redesign [79], organizational assimilation of IT [80], innovation diffusion [11], and IT strategy [81]. IT innovation focuses on adopting IT products and or services to integrate core business competencies and support the administrative task of IT functions [82]. IT innovation capabilities are unique and valuable resources of a firm with great potential to contribute to competitive performance [83] and leveraging structural resource differences including diversification, flexibility, and quality among competing firms [84]. Using the unique capabilities of information technology, firms are able to fuse IS and business knowledge to ensure that technological innovation is captured at strategy conception [85], improve their innovation capabilities [86] and innovative performance [87] since innovation process is knowledge intensive [88].

\section{iii. IS Support for Strategic Alignment Factors}

There are several factors that enable or inhibit strategic alignment. Some of these factors include organizational learning [89], firm-wide involvement in strategic planning [90], organizational structure and culture [91], purposeful and strategically focused communication [64], collaboration to share knowledge and skills among business staff and IT staff [53], management skill and commitment to strategic alignment process [90], and well-prioritized strategic IT projects [92].
The convergence of computing, communications, and content technologies have heightened the significance of IT in enabling agile competitive moves [74]. Requisite assets, knowledge, and relationships that are needed to achieve innovation goals and competitive advantage are timely and effectively organised [93]. Organizational learning is considered as one of the strategic tools for achieving long-term organizational success [94]. Learning organisations are agile and more flexible to respond to new challenges in their environment than competitors [95]. Information technology facilitates the efforts of learning organizations to create and manage new knowledge and capabilities that are difficult to imitate to support innovation activities [96] in new product design, reduction in product development cycle and cost, and improving product quality [97]. Information technology enhances cross-unit knowledge management capability of an organisation to master change, leverage resources, and cooperate to compete that eventually influences its performance [98] [138].

\section{iv. IS Support for Strategic Assets}

A bundle of tangible and intangible resources ("stocks of available factors that are owned or controlled by the firm" [99]) and capabilities (strategic application of competencies to accomplish organizational goals [18]) that are difficult to trade and imitate, scarce, and specialized whose economic returns impact the competitive advantage of a firm are its strategic assets [56]. Strategic asset has a direct effect (efficiency effect) on performance [100] and impacts directly on strategy since they enhance a firm's capability to design competitive strategies such as product differentiation, cost reduction, etc. [50]. Managerial competence to make a subjective decision on the allocation, deployment and maintenance of resource results in a better return on capital and gaining or sustaining competitive advantage [101] in the mist of the economic, industrial, regulatory, and social issues, technological uncertainties, the behaviour of competitors, and customers' preferences among others. The sustainability of such competitive advantage over the long-term can be achieved through unique resources (resource heterogeneity) that are too costly or difficult to imitate, simultaneously valuable, rare, imperfectly imitable, and appropriately support or are exploited by existing organizational processes [56].

IS executives must look beyond their own IT domain and concentrate on cultivating resources that help the firm understand changing business environments. [102] classifies key IS-based resources as the tangible resource consisting the physical IT infrastructure components, the human IT resources including the technical and managerial IT skills, and the intangible IT-enabled resources such as knowledge assets. The rareness and firm-specific nature of managerial IT skills make them sources of sustained competitive advantage [50]. Human IT asset, technical asset, and a strong IT-business relationship influence the ability of a firm to deploy IT for strategic objectives [81]. However, the acquisition, deploying, and leveraging of IS resources to shape and 
support business strategies and value chain activities depends on the IS capabilities of a firm [65]. Through IS capability, business and IS knowledge can be fused; a flexible and reusable IT platform is developed; organisations innovate with IS/IT to effect change and to adapt business processes and practices (often referred to as agility) [85]; and organisations gain a sustained competitive advantage and superior performance [56]; [103]. Empirically, IT support for strategic assets contributes to the performance of a firm [92]. IT derives its strategic value from the complementary use of capabilities and resources (strategic assets) that are inherently valuable and defines the essence of strategy [56]. In relative terms, deploying complementary strategic assets may increase the strategic value of each asset.

\section{DATA COllection AND METHOD}

The study adopted a qualitative method to explore the findings. The interpretive nature of the research expedited the response (subjective data) needed to understand the impact of the alignment or lack of it between IS strategy and technological innovation on the performance of a firm. Since this study has not been conducted among the universal banks in Ghana, using the qualitative approach was appropriate to explore and understand phenomena emerging in the natural settings of these firms that result from their interactions with organizations, people, and technology [104]. Meaning-making primary data that produced detailed descriptions of the situations and events were gathered through personal interviews, inductively analysed to build patterns, and organized these patterns into categories [105].

With no control over the events at where this study was conducted, a case study was used appropriately to define the unit of analysis that were studied [106] over a sustained period of time to gather in-depth data. Eleven (11) participants that hold managerial positions from six (6) universal banks in Ghana and could decisively inform an understanding of the research problem and the central phenomenon were purposefully selected for the study. These participants were made up of four (4) national heads of IT/Technology, three (3) regional/area managers, two (2) branch managers, one (1) regional/area sales manager, and one (1) branch sales manager. Any consensus that ensued from the semi-structured interviews conducted with these participants in 2015 was considered valuable in understanding business-IT strategic alignment related issues and opportunities [53] for they are considered most knowledgeable in their business strategies, IT strategies, and performance assessment.

A case study is mainly criticised for lack of a standard analysis approach [107]. Complementing grounded theory with case study is appropriate due to its rigorous data coding and analysis procedures. Following the grounded theory design, data collection was followed immediately by or concurrent with analysis for the purpose of generating findings that were empirically valid and firmly grounded in empirical data [108]; [109]; [110]. The study adopted the analytical approach to grounded theory, the most common approach in IS research, and an emerging strand that tilts towards the Straussian [111].

\section{A. Measuring Alignment and Performance}

The most common measures that IS researchers use to assess strategic IT alignment are the matching, moderation, and profile deviation [112], however, their underlying conceptual assumptions of what constitutes fit and operationalization differ [113] leading to different and perhaps even contradictory findings [114]. In this study, the direct approach of self-typing to measure business-IT strategic alignment [115] was used to determine the alignment between technological innovation and IT strategy. Participants were directly asked to determine the extent of alignment between IT and business strategies [116] (how IS supports technological innovation), shared knowledge and understanding between business and IT executives [67], and whether alignment impacts the performance of their firms.

On performance measurement, respondents were asked to indicate if their firms set specific performance goals, how frequent these goals occur or change, metrics used to measure performance and whether they are similar to those of other firms in the industry, and the levels of their performance. This approach of measuring performance has been found among those used in [117], [118], and [119]. In situations where the intent of the researcher is to summarize the information for the purpose of getting the underlying meaning, descriptive statistics are commonly used to accomplish this task [120].

\section{DATA ANALYSIS AND FINDINGS}

In an effort to enhance the quality of the interpretation of the interviews data and holding the epistemological principles consistent, a qualitative dominant crossover mixed analysis [121] to reduce the dimensionality of the qualitative findings was employed. Thus, the study followed integrative analytical technique [122] to complement and present a more comprehensive view of the findings. The semantic relationships among categories were mapped instead of examining just the frequency counts of words or phrases that formed each category [123]. To present objective results, frequencies generated from initial data analysis in Nvivo were further analysed using correspondence analysis technique in SPSS. The study used a multidimensional performance measurement approach to capture internally reflective financial and non-financial measures that are complementary. 
A. Facilitating the Coding Process with ComputerAssisted Qualitative Data Analysis Software (CAQDAS)

The grounded theory coding processes and managing the transcripts of the interviews were facilitated efficiently using Nvivo 10, a CAQDAS. Nvivo simplified the coding task considerably and increased the validity and reliability of the results [124].

Table 1. Distribution of categories mentioned per participant

\begin{tabular}{|c|c|c|c|c|c|c|c|c|c|c|c|c|}
\hline \multirow[b]{2}{*}{ Category } & \multicolumn{12}{|c|}{ Participant } \\
\hline & $\begin{array}{l}\text { B01 } \\
\text { AM }\end{array}$ & $\begin{array}{c}\text { B01 } \\
\text { BSM }\end{array}$ & $\begin{array}{l}\text { B01 } \\
\text { HT }\end{array}$ & $\begin{array}{l}\mathrm{B} 02 \\
\mathrm{BM}\end{array}$ & $\begin{array}{l}\text { B02 } \\
\text { HIT }\end{array}$ & $\begin{array}{l}\mathrm{B} 02 \\
\mathrm{ZM}\end{array}$ & $\begin{array}{c}\text { B03 } \\
\text { BSSM }\end{array}$ & $\begin{array}{c}\text { B04 } \\
\text { HAE }\end{array}$ & $\begin{array}{l}\text { B04 } \\
\text { RM }\end{array}$ & $\begin{array}{l}\text { B05 } \\
\text { BM }\end{array}$ & $\begin{array}{l}\text { B06 } \\
\text { SEA }\end{array}$ & Total \\
\hline EoA_PAL & 0 & 0 & 0 & 0 & 1 & 0 & 0 & 0 & 0 & 0 & 0 & 1 \\
\hline EoA_WAL & 1 & 1 & 1 & 1 & 0 & 1 & 1 & 4 & 1 & 0 & 1 & 12 \\
\hline ISSSA & 1 & 2 & 13 & 1 & 18 & 0 & 1 & 22 & 1 & 3 & 18 & 80 \\
\hline ISSTI & 28 & 19 & 91 & 23 & 94 & 26 & 14 & 88 & 25 & 18 & 83 & 509 \\
\hline SAF & 63 & 57 & 49 & 65 & 49 & 59 & 59 & 53 & 67 & 69 & 49 & 639 \\
\hline SAOPI & 3 & 2 & 13 & 4 & 9 & 2 & 3 & 15 & 1 & 3 & 14 & 69 \\
\hline
\end{tabular}

\section{i. Open Coding}

First, word frequency query was performed to identify frequently mentioned words or phrases that guided the understanding of what participants were saying. For close examination and identification of concepts, each transcript was read line-by-line. Nodes were created to store the relevant text of new possibilities that emerged from data as concepts. The underlying uniformity, varying conditions, implicit meanings, and actions for relating the data to specific nodes that contain such data similarities were established using the Boolean logic based coding query. Memos were created to record ideas that explain the emerging concepts and their interrelationships for further exploration of concepts. Over 50 concepts were produced for further analysis.

\section{ii. Axial Coding}

Relationships between concepts identified at open coding were reassembled using the relationship node tool in NVivo. After exploring other concepts and segments of potentially relevant data through constant comparison of the similarities and differences, concepts were related to each main identified phenomenon (specific abstract concept) and represented them as categories (see Appendix 2).

\section{iii. Selective Coding}

Categories identified at axial coding were refined and integrated into core categories. Thus, nodes representing categories were clustered into broader categories based on potentially meaningful relationships using NVivo exploratory tool. Nine core categories (see Appendix 1) were finally obtained.

For further analysis in SPSS using the correspondence analysis (CA) technique, a two-way frequency table (contingency table) (see Table 1), that shows the number of occasions a particular issue was raised for each of the nine core categories was extracted using the Matrix coding query tool in NVivo.

The details that constitute each category are found at Appendixes 1 and 2.

\section{B. Propositions}

The propositions for the study were developed from direct quotations or statements made by participants.

These propositions were to facilitate the investigation of strategic alignment between IS and technological innovation (IS support technological innovation as a business strategy) if any, the extent of the alignment, factors that contribute to the alignment, and how the alignment impacts the performance of a firm.

\section{Research Proposition 1:}

Several factors contribute to the positive impact of the strategic alignment between IS and technological innovation on the performance of a firm.

Participant B05BM indicates that "Industry forces impact innovation efforts. The market has become dynamic because customers keep changing preferences. New market entrants always bring innovation. It's a global village, so whatever happens in the industry affects all”. According to B04RM, "A bank can come out swith a product that can sway several customers. MTN money impacts seriously on the banks"; "People are coming from different environments to compete, and there are always new things. If you don't act, you would be left behind" (B02HIT); and "Activities going on in the industry will push us to innovate" (B03BSSM). These statements resulted in proposition 1a.

1a Business challenge directly impacts technological innovation efforts.

According to B02HIT, "The current and planned use of IT is to support strategic assets including organizational, marketing, and technological 
competencies. We use IT to support strategic assets to achieve business efficiency, improve performance, enhance effectiveness, cost reduction, increase quality and speed, flexibility and responsiveness to customer needs". Manager B05BM indicates that "IT has contributed and still contributes to our performance. High levels of efficiency and productivity for less time is spent, infrastructure has been simplified, work is made easier, much time with customer". Proposition $1 \mathrm{~b}$ is derived from the above statements.

1b IS support for strategic assets impacts the alignment between IS and technological innovation.

A participant, B02HIT indicates that "Innovative performance impacted our profitability between 2012 and 2014. Profitability has been going up; overall performance of the company is good year by year". According to B04HAE, "Yes, 100\% IT has contributed to the performance of our firm through technological changes that have been done to enable the business to sell products, provide solutions to customers, and improvement in terms of reporting." "We align business and IT to cut cost, enhance productivity, and creates an opportunity for efficiency" (B01AM) and B02HIT indicates "We have successfully aligned technological innovation and information technology strategy with positive effects on firm performance". Participant B02HIT indicates "Technological innovation has impacted our firm's performance because it helps reduce operational costs, increases efficiency, and attract more customers. Innovative processes make executing job efficient leading to improved productivity, while innovative products attract customers - in turn increasing turnover." Proposition $1 c$ resulted from the above statements.

1c IS support for technological innovation impacts positively on firm performance.

According to B02ZM, "Our IT platforms are agiler. To improve agility, our priorities fall on process efficiency, knowledge management, collaboration across the business and beyond, and increasing overall employee productivity". Some participants indicate "communication, collaboration, understanding business strategy and how technology can fit into it to promote alignment" (B01HT); "management support, human resource, customer's satisfaction, competition” (B04RM) "collaboration between IT and business units" (B04HAE), "cross-functional engagement” (B05BM); "management support, knowledge sharing, competent personnel, established organizational structure" (B06SEA); "technology people understanding the business and trying to use technology to drive the business" (B02HIT) as factors that promote alignment between IS and technological innovation. Hence, Proposition Id is derived.

1d Strategic alignment factors directly impact the alignment between IS and technological innovation.

\section{Correspondence Analysis}

Correspondence analysis is an exploratory multivariate method that facilitates and improves the interpretation of complex data, determines accurately the relations between different categorical variables that are scaled nominally [125], and represents both linear and nonlinear relationships equally well. Findings are communicated with more objectively summarized information that involves cross comparisons between many variables in a small number of dimensions using a visual perceptual mapping approach (biplots) [126]; [127]. The two-way frequency table generated from grounded theory analysis (see Table 1) was used as input to the correspondence analysis conducted in the SPSS of this study.

The results of the correspondence analysis are shown in Tables 2, 3, and 6. Following the steps set out in [127] pp. 601-606), communicating the findings was improved through visual inspection of the two-dimensional perceptual map (Fig. 1) and assessment of the statistical measures. Fig. 1 represents the principal coordinates of the rows and the columns that interpret the relative but not actual magnitude of the distances between points using the correspondence analysis symmetrical normalisation option. The summary table, Table 2 shows the output for the 11 participants and 9 categories. It contains the singular values, inertia, and proportion of variation explained for ten (10) dimensions.

$i$. Assessing the significance of the association between the row and column points

The measure of statistical association between rows and columns is determined by the total inertia $(0.238$, see Table 2) and can be calculated as the total chi-square value (398.107) divided by $N$ (the total of the frequency counts, 1671). The total inertia of .238 exceeds the minimum threshold of .2 for an acceptable solution making the row-column correlation significant [126]; [127]. A $p$-value of $<0.001$ indicates a strong dependency in the data. CA represents all the locations of the data points with a small number of dimensions through the decomposition of the overall inertia.

\section{ii. Number of Dimensions to Retain}

In this study, there were eleven participants (representing six firms) and 9 categories. The maximum number of dimensions to capture $100 \%$ of the inertia was 8 (number of active rows minus 1 or the number of active columns minus 1 whichever is less) (see Table 3 ). The sum of the inertia of dimensions 1 and 2 is $.230(.220$ +.010 ; column 3 in Table 3 ). Together they explained $92.2 \%+4.2 \%(96.4 \%)$ of the total inertia and were retained for further examination [128]. This conforms to the recommendation of [127] to retain CA dimensions until the total inertia is greater than .2 .

\section{iii. Interpreting and Naming the Dimensions}

The columns labelled 1 and 2 of Table 3 are the inertia values for dimensions 1 and 2 and indicate how well a category is represented in the two-dimensional perceptual 
map. A value that exceeds .5 in the 'Total' column is considered evidence of a well-represented category in the overall two-dimensional correspondence solution [127].

For representing the participants in the twodimensional perceptual map, a value that exceeds $50 \%$ in the 'Total' column is considered evidence of a wellrepresented participant in the solution [126]. All participants met the cut-off of $50 \%$ and were well represented in the two-dimensional solution (see Table 4). All participants are strongly associated with dimension 1 with inertias greater than .5 considering the above cut-off criterion.

The two dimensions on the perceptual map were assigned names by focusing on the participants' positions relative to the categories. Categories that contribute significantly to the total inertia of each of the two dimensions of the perceptual map were retained during the naming process [129]. Columns 1 and 2 under

The Contribution of Point to Inertia of Dimension of Table 3 determines the magnitude of the contributions. Each significant category made a contribution more on average than the other categories of $>11.1 \%$ (100 divide by 9 - total number of categories) to the total inertia of a dimension. Dimension 1, the first principal axis (plotted as the horizontal axis on the perceptual map) accounts for
$92.2 \%$ of the total inertia (see Table 2 ).

Using the cut-off point of $11.1 \%$ and by observing the categories under the Contribution of Point to Inertia of Dimension column in Table 2 (see numbers in brackets), the categories in Table 4 were considered significant on Dimension 1.

Dimension 2, the second principal axis (plotted as the vertical axis on the perceptual map) accounts for $4.2 \%$ of the total inertia (see Table 2). Using the cut-off point of $11.1 \%$ and by observing the categories under the Contribution of Point to Inertia of Dimension column in Table 3 (see numbers in brackets), the categories in Table 5 were considered significant on Dimension 2.

The labels of end points of the dimensions of the perceptual map (Fig. 1) are provided using the significant categories identified in Table 4 and Table 5. The dimension coordinates (columns 1 and 2 under the Score in Dimension of Table 3) for plotting the category points on the perceptual map facilitate a better understanding of participants' perceptions on IS strategy and technological innovation alignment. The squares on the map represent the categories and the circles indicate the eleven participants. For the participants, the managers are positioned left and IT heads right on the perceptual map, and very close to the centroid.

Table 2. Overall summary of the correspondence analysis

\begin{tabular}{|c|c|c|c|c|c|c|c|c|}
\hline \multirow[b]{2}{*}{ Dimension } & \multirow[b]{2}{*}{$\begin{array}{l}\text { Singular } \\
\text { Value }\end{array}$} & \multirow[b]{2}{*}{ Inertia } & \multirow[b]{2}{*}{ Chi Square } & \multirow[b]{2}{*}{ Sig. } & \multicolumn{2}{|c|}{ Proportion of Inertia } & \multicolumn{2}{|c|}{ Confidence Singular Value } \\
\hline & & & & & $\begin{array}{l}\text { Accounted } \\
\text { for } \\
\end{array}$ & Cumulative & $\begin{array}{c}\text { Standard } \\
\text { Deviation } \\
\end{array}$ & Correlation 2 \\
\hline 1 & .469 & .220 & & & .922 & .922 & .021 & .018 \\
\hline 2 & .100 & .010 & & & .042 & .964 & .025 & \\
\hline 3 & .062 & .004 & & & .016 & .980 & & \\
\hline 4 & .052 & .003 & & & .011 & .991 & & \\
\hline 5 & .033 & .001 & & & .004 & .996 & & \\
\hline 6 & .025 & .001 & & & .003 & .998 & & \\
\hline 7 & .018 & .000 & & & .001 & 1.000 & & \\
\hline 8 & .010 & .000 & & & .000 & 1.000 & & \\
\hline Total & & .238 & 398.107 & $.000^{\mathrm{a}}$ & 1.000 & 1.000 & & \\
\hline
\end{tabular}

Table 3. Determining the appropriate dimensionality of a perceptual map for participants.

\begin{tabular}{|c|c|c|c|c|c|c|c|c|c|}
\hline \multirow[b]{2}{*}{ Categories } & \multirow[b]{2}{*}{ Mass } & \multirow{2}{*}{$\begin{array}{c}\text { Sore in } \\
\text { Dimension } 1\end{array}$} & \multirow{2}{*}{$\begin{array}{c}\text { Sore in } \\
\text { Dimension } 2\end{array}$} & \multirow[b]{2}{*}{ Inertia } & \multicolumn{2}{|c|}{$\begin{array}{l}\text { Contribution of Point to } \\
\text { Inertia of Dimension }\end{array}$} & \multicolumn{3}{|c|}{$\begin{array}{l}\text { Contribution of Dimension to } \\
\text { Inertia of Point }\end{array}$} \\
\hline & & & & & Inertia 1 & Inertia 2 & Inertia 1 & Inertia 2 & Total \\
\hline $\mathrm{BC}$ & .130 & -.734 & .103 & .033 & [.149] & .014 & .991 & .004 & .995 \\
\hline EoA_PAL & .001 & 1.656 & 6.586 & .005 & .004 & {$[.259]$} & .163 & .551 & .714 \\
\hline EoA_WAL & .007 & .137 & -1.829 & .004 & .000 & {$[.240]$} & .015 & .573 & .588 \\
\hline FP & .064 & -.994 & .027 & .030 & {$[.135]$} & .000 & .980 & .000 & .980 \\
\hline ISSSA & .048 & 1.274 & -.324 & .039 & {$[.166]$} & .050 & .936 & .013 & .949 \\
\hline ISSTI & .305 & .729 & .195 & .078 & {$[.345]$} & [.116] & .976 & .015 & .991 \\
\hline SAF & .382 & -.412 & -.014 & .031 & {$[.138]$} & .001 & .989 & .000 & .989 \\
\hline SAOPI & .041 & .836 & -.624 & .016 & .062 & {$[.161]$} & .859 & .102 & .961 \\
\hline SI & .022 & -.139 & -.849 & .003 & .001 & [.159] & .067 & .537 & .604 \\
\hline Active Total & 1.000 & & & .238 & 1.000 & 1.000 & & & \\
\hline
\end{tabular}

a. Symmetrical normalization 
Table 4. Dimension 1 significant categories

\begin{tabular}{|c|c|c|c|}
\hline \multicolumn{2}{|c|}{$\begin{array}{l}\text { Categories left side of } \\
\text { Perceptual map }\end{array}$} & \multicolumn{2}{|c|}{$\begin{array}{l}\text { Categories right side of } \\
\text { Perceptual map }\end{array}$} \\
\hline $\mathrm{BC}$ & $14.9 \%$ & ISSTI & $34.5 \%$ \\
\hline FP & $13.5 \%$ & & \\
\hline SAF & $13.8 \%$ & & \\
\hline ISSSA & $16.6 \%$ & & \\
\hline
\end{tabular}

Table 5. Dimension 2 significant categories

Table 6. Determining the appropriate dimensionality of a perceptual map for categories.

\begin{tabular}{|c|c|c|c|c|c|c|c|c|c|}
\hline \multirow[b]{2}{*}{ Participants } & \multirow[b]{2}{*}{ Mass } & \multirow{2}{*}{$\begin{array}{c}\text { Score in } \\
\text { Dimension } 1 \\
\end{array}$} & \multirow{2}{*}{$\begin{array}{r}\text { Score in } \\
\text { Dimension } 2 \\
\end{array}$} & \multirow[b]{2}{*}{ Inertia } & \multicolumn{2}{|c|}{$\begin{array}{l}\text { Contribution of Point to Inertia } \\
\text { of Dimension }\end{array}$} & \multicolumn{3}{|c|}{$\begin{array}{c}\text { Contribution of Dimension to } \\
\text { Inertia of Point }\end{array}$} \\
\hline & & & & & Dimension 1 & Dimension 2 & 1 & 2 & Total \\
\hline B01AM & .083 & -.533 & .004 & .012 & .050 & .000 & .958 & .000 & .958 \\
\hline B01BSM & .071 & -.634 & .018 & .014 & .061 & .000 & .975 & .000 & .975 \\
\hline B01HT & .110 & .727 & .133 & .029 & .124 & .019 & .924 & .007 & .930 \\
\hline B02BM & .083 & -.604 & -.107 & .014 & .064 & .009 & .975 & .007 & .982 \\
\hline B02HIT & .113 & .776 & .660 & .037 & .145 & 489 & .847 & .131 & .978 \\
\hline B02ZM & .078 & -.604 & .195 & .014 & .061 & .030 & .931 & .021 & .952 \\
\hline B03BSSM & .069 & -.702 & -.256 & .017 & .072 & .045 & .942 & .027 & .968 \\
\hline B04HAE & .121 & .747 & -.512 & .036 & .144 & .316 & .884 & .089 & .973 \\
\hline B04RM & .083 & -.623 & .127 & .016 & .068 & .013 & .964 & .009 & .973 \\
\hline B05BM & .081 & -.665 & .016 & .018 & .077 & .000 & .935 & .000 & .936 \\
\hline B06SEA & .110 & .757 & -.266 & .031 & .134 & .078 & .945 & .025 & .970 \\
\hline $\begin{array}{l}\text { Active } \\
\text { Total } \\
\end{array}$ & 1.000 & & & .238 & 1.000 & 1.000 & & & \\
\hline
\end{tabular}

a. Symmetrical normalization

\section{Corroborating the Plotting Points on the Perceptual} Map and Literature to Confirm the Propositions

The perceptual map as a multi-dimensional map provided the means for directly comparing the similarity or dissimilarity of both the participants and the associated categories. All seven managers on the perceptual map (Fig. 1) are plotted very close to each other at the left side, and their plotting points along both dimensions are closer to Firm Performance, Business Challenge, Strategic
Alignment Factors, Strategic Intent, and Alignment Extent of Well-Aligned. All four IT heads on the perceptual map are plotted at the right side with each closer to other. Their plotting points along both dimensions are closer to IS Support for Technological Innovation, IS Support for Strategic Assets, Positive Impact of Strategic Alignment Outcome, Strategic Intent, and Alignment Extent of Well-Aligned.

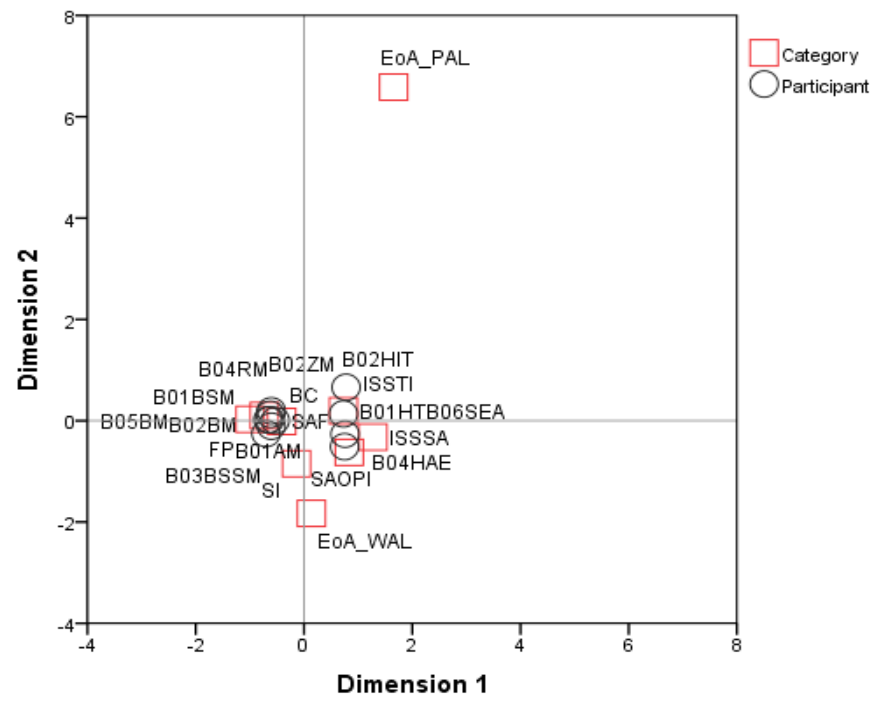

Fig.1. The perceptual map of participants and categories 
1a Business challenge directly impacts technological innovation efforts.

Greater environmental hostility is related to lower innovative performance [77]. However, the closeness of Business Challenge plotting point on the perceptual map (Fig. 1) to ISSTI and Firm Performance might be explained by the fact that managers were able to explore the relationships between resources, competition, and profitability at the business strategy level [56] to exploit environmental opportunities or neutralize threats [57].

Thus, a business challenge can directly impact innovation efforts if management does not strategize properly. These confirm proposition $1 b$

1b IS support for strategic assets impacts the alignment between IS and technological innovation.

The close relationship between ISSSA and ISSTI confirms the view of [118] and [77] that increased IT support for strategic assets positively determines the configuration of strategic activities. ISSSA positioned close to SAOPI indicates the firms use the unique capabilities of information technology to fuse IS and business knowledge to improve their capabilities to innovate [86]. A strong partnering relationship between a firm's IT and business unit management influence a firm's ability to deploy IT for strategic objectives [81]. Proposition $1 b$ is confirmed since IT derives its strategic value from the complementary use of capabilities and resources (strategic assets) that are inherently valuable and defines the essence of strategy [56].

1c IS support for technological innovation impacts positively on firm performance.

The close relationship between ISSTI and ISSSA aligns with the work of business-IT researchers such as [118] and [77] who are of the view that the use of IT to leverage firm capabilities has both an indirect and a direct effect on performance. IT supports technological innovation to enhance service fulfilment, deliver products efficiently, decrease operational cost [30] thereby maximizing value for customers, and improves the firm's performance. The interrelationship among SAOPI, SI, ISSTI, EoA_WAL and FP show a positive relationship between innovation and performance [130] that resulted from the strategic use of IS [116]. Proposition $1 c$ is confirmed.

1d Strategic alignment factors directly impact the alignment between IS and technological innovation.

The effects of IT alignment manifest on specific intermediate performance variables [112]. The close relationship between SAF and ISSTI indicates partnership between IT professionals and business leaders to collaborate in enhancing the creation and execution of knowledge purposely for innovation activities [131]. SAF positioned between managers and IT heads indicates strong communication and collaboration [132], strategic planning [133], organizational culture [134], and IT- business knowledge sharing [67] might have eventually affected the outcome of any strategy implementation initiatives of the firms. These firms through organizational learning were able to develop new knowledge and capabilities that are difficult to imitate [89] to support their strategic intent. In this sense, strategic alignment factors directly impact the alignment between IS and technological innovation which confirms proposition $1 d$.

\section{DisCUSSION AND CONCLUDING REMARKS}

This research paper reports on the impact of strategic alignment between IS strategy and technological innovation among six (6) universal banks in the Ghanaian banking industry. The study draws on eleven (11) participants and contributes to the large body of research on the organizational sources of sustainability. Perceptually, IS-business strategic alignment impacts the performance of a firm. Our study discloses how eight categories (factors) influence strategic alignment that in turn impacts the performance of a firm. These categories and participants were considered significant, well-related, and were well-represented in the solution. Managers are closely associated with the business challenge, strategic alignment factors, and firm performance while IT heads are related to IS support for strategic assets, IS support for technological innovation, and positive outcome of strategic alignment. The extent of alignment and strategic intent are positioned between managers and IT heads. This implies strategically, managers and IT heads collaborated to foster strategic alignment that yielded positive strategic alignment outcome.

The findings are consistent with the claim that strategic alignment impacts the performance of a firm. However, successful IS-business strategic alignment requires the collaboration between functional areas, management commitment, agility to respond to external threats, embarking on IS strategic projects to realise the contributions of IT, organizational learning, and ability to address alignment inhibitors. Strategic alignment must focus on the strategic intent of a firm to result in successful alignment with a positive outcome to contain business challenges. This is observed on the perceptual map (Fig. 1) of the close relationship among business challenge, IS support for technological innovation, strategic alignment factors, the extent of alignment, strategic intent, and positive outcome of strategic alignment. Partial alignment does not result in a full realisation of strategic intent, hence, it is positioned far from the rest of strategic alignment categories. IS support for strategic assets contributes immensely to successful alignment through its influence on IS support for technological innovation. The findings confirm this. It is evidence that the multidimensional approach to performance measurement where factors are complementary could better predict the performance levels of firms. Propositions $1 \mathrm{a}, 1 \mathrm{~b}, 1 \mathrm{c}$, and $1 \mathrm{~b}$ that collectively address the notion that several factors contribute to the positive impact of the strategic 
alignment between IS and technological innovation on the performance of a firm are confirmed.

The study followed the systematic procedure of grounded theory design and focused mainly on the alignment between specific functional areas making it possible to perform an effective assessment of strategic alignment in a quest to achieve a sustainable competitive advantage. The objective results obtained from the correspondence analysis with a p-value $<0.001$ (indicating strong dependency in the data) and the twodimensional solution accounting for $96.4 \%$ of the total variance in the categories associations provide some important managerial and practitioner implications. Managers and IT practitioners are provided with significant, specific, and reliable alignment factors that could help in assessing and determining the strategic alignment dimensions that contribute more or less to firm performance.

Clearly, several factors impact firm performance through other mediating factors. The performance of a firm is not directly affected by strategic IT alignment [112], rather, the effects occur where key organizational and management variables are mutually 'fit' [135]. Thus, "alignment focuses on the activities that management performs to achieve cohesive goals across the organisation" [136] p. 3. Long-term efficiency of an organization depends on the strong interdependencies among internal organizational attributes [38]. The interactions among bundles of practices predict better performance than practicing in isolation [137], therefore, the strategic value of IT can be realized if it is used complementarily with resources and capabilities of a firm [56]. The study complements ISSSA, ISSTI, strategic alignment factors (SAF), and BC to better predict the impact of strategic alignment instead of relying solely on ISSTI.

The factors that were used to assess the impact of strategic alignment on the performance of a firm were derived from comments made by participants. This may suggest the factors were not extensive, however, using the qualitative method, a total of 1671 frequency counts (meaningful ideas) by participants represent enormous data to produce credible results.

ApPendix 1. Selective Coding CoRe CATEgories

\begin{tabular}{|c|c|c|}
\hline Axial Coding Category & Category & Core Category \\
\hline Firm Performance & & Firm Performance (FP) \\
\hline Strategic Alignment Impact & & Strategic Alignment Impact (SAOPI) \\
\hline Extent of Alignment & & Extent of Alignment (EoA) \\
\hline $\begin{array}{l}\text { Internal Business Challenge } \\
\text { Eternal Challenges (Industry Forces) }\end{array}$ & Business Challenge & Business Challenge (BC) \\
\hline $\begin{array}{l}\text { Agility } \\
\text { Collaboration }\end{array}$ & & \multirow{5}{*}{ Strategic Alignment Factors (SAF) } \\
\hline $\begin{array}{l}\text { IS Projects Strategic Value } \\
\text { Management Commitment }\end{array}$ & & \\
\hline IT Contribution & & \\
\hline Organizational Learning & & \\
\hline Alignment Inhibitors & & \\
\hline $\begin{array}{l}\text { IS Conservative } \\
\text { IS Innovator }\end{array}$ & IS Strategy & \multirow{6}{*}{ IS Support for Technological Innovation (ISSTI) } \\
\hline $\begin{array}{l}\text { Innovation Challenges } \\
\text { Innovation Capabilities }\end{array}$ & \multirow{5}{*}{ Technological Innovation } & \\
\hline Innovation Objectives & & \\
\hline Innovativeness & & \\
\hline Process Innovation & & \\
\hline Product Innovation & & \\
\hline IS Support for Strategic Asset & & IS Support for Strategic Asset (ISSSA) \\
\hline
\end{tabular}


APPENDIX 2. AXIAL CODING CATEGORIES

\begin{tabular}{|c|c|}
\hline Concept & Category \\
\hline \multicolumn{2}{|l|}{ Well-Aligned (EoA_WAL) } \\
\hline Partially-Aligned (EoA_PAL) & \multirow[t]{2}{*}{ Extent of Alignment } \\
\hline Not- Aligned (EoA_NAL) & \\
\hline Strategic Alignment Outcome & \multirow{2}{*}{ Strategic Alignment Impact } \\
\hline Strategic Intent & \\
\hline \multicolumn{2}{|l|}{ Established Organizational Structure \& Culture } \\
\hline Functional Engagement & \multirow{3}{*}{ Collaboration } \\
\hline Management Support \& Personnel Competency & \\
\hline Collaboration & \\
\hline IS Projects Strategic Value & IS Projects Strategic Value \\
\hline Management Commitment & Management Commitment \\
\hline Alignment Inhibitors & Alignment Inhibitors \\
\hline \multicolumn{2}{|l|}{ Balance Sheet Management } \\
\hline \multicolumn{2}{|l|}{ Competition among Functional Areas } \\
\hline \multicolumn{2}{|l|}{ Cost Management } \\
\hline \multicolumn{2}{|l|}{ Customer Management } \\
\hline Innovation & \multirow{6}{*}{ Internal Business Challenge } \\
\hline Mergers \& Acquisitions & \\
\hline \multirow{4}{*}{$\begin{array}{l}\text { Organizational Restructuring } \\
\text { People Management } \\
\text { Risk Management } \\
\text { Technology }\end{array}$} & \\
\hline & \\
\hline & \\
\hline & \\
\hline \multicolumn{2}{|l|}{ Rivalry of Competitors } \\
\hline Threats of New Entrants & \multirow[t]{2}{*}{ External Business Challenge } \\
\hline Threats of Substitute Products & \\
\hline \multicolumn{2}{|l|}{ Firm Performance Goal } \\
\hline Firm Performance Metric & \multirow[t]{2}{*}{ Firm Performance } \\
\hline Performance Measurement System & \\
\hline Agility & Agility \\
\hline Organizational Learning & Organizational Learning \\
\hline IS Conservative & IS Conservative \\
\hline IS Innovator & IS Innovator \\
\hline IT Contribution & \multirow{2}{*}{ IT Contribution } \\
\hline Formulated IT Strategy & \\
\hline \multicolumn{2}{|l|}{ IS Capability } \\
\hline IS Competence & \multirow[t]{2}{*}{ IS Support for Strategic Asset } \\
\hline IS Resources & \\
\hline Innovation Capabilities & \\
\hline Innovation Drivers & Innovation Capabilities \\
\hline Innovation Challenges & Innovation Challenges \\
\hline Innovation Objectives & \\
\hline Formalised Innovation Strategy & Innovation Objectives \\
\hline Successful Innovation Initiatives & \\
\hline Level of Innovativeness & Technological Innovativeness \\
\hline Unique Product and Process & \\
\hline Process Innovation Measures & \\
\hline Process Innovation Objectives & \\
\hline Mode of Implemented Process Innovation & Process Innovation \\
\hline Sources of Implemented Process Innovation & \\
\hline Product Innovation Measures & \\
\hline Product Innovation Objectives & Product Innoyation \\
\hline Mode of Implemented Product Innovation & Product Innovation \\
\hline Sources of Implemented Product Innovation & \\
\hline
\end{tabular}




\section{REFERENCES}

[1] Bank of Ghana. Register of Licensed Institutions. Available Online: https://www.bog.gov.gh/index.php?option=com_content\& view $=$ article $\&$ id $=110 \&$ Itemid=123 Accessed on 15 th May 2016.

[2] Y. Kim, T. Kelly, and S. Raja. "Building Broadband: Strategies and Policies for the Developing World". Global Information and Communication Technologies (GICT) Department, World Bank, Washington, DC, 2010.

[3] P. W. Roberts and R. Amit. "The dynamics of innovative activity and competitive advantage: the case of Australian retail banking, 1981 to 1995 ". Organization Science, vol. 14, pp. 107-122, 2003.

[4] J. A. O'Brien \& G. M. Marakas. Management Information Systems. New York: The McGraw-Hill Companies, Inc., 2011.

[5] Z. Rylková \& W. Bernatík. "Contemporary Issues in Business, Management and Education 2013 Performance measurement and management in Czech enterprises". Procedia-Social and Behavioral Sciences, vol. 110, pp. $961-968,2014$.

[6] J. Gartlan \& G. Shanks. "The Alignment Of Business And Information Technology Strategy In Australia". Australasian Journal of Information Systems, vol. 14, no.2, pp. 1-10, 2007.

[7] J. S. Chen \& H. T. Tsou. "Information Technology Adoption for Service Innovation Practices and Competitive Advantage: The Case of Financial Firms". Information Research, vol. 12, no.3, paper 314, 2007.

[8] M. E. Porter \& V. E. Millar. "How information gives you competitive advantage". Harvard Business Review, vol. 63, no.4, pp. 149-160, 1985.

[9] P. G. W. Keen. Shaping the future- Business design through information technology. Boston, MA: Harvard Business School Press, 1991.

[10] J. Rockart \& M. Scott Morton. "Implications of changes in IT for corporate strategy". Interfaces, vol. 14, no.1, pp. 83-95, 1984.

[11] M. Bofondi \& F. Lotti. "Innovation in the retail banking industry: the diffusion of credit scoring". Review of Industrial Organization, vol. 28, no.4, pp. 343-358, 2006.

[12] K. Lal. "Consequences of the Adoption of Information and Communication Technologies in SME's in Jamaica". The Icfai Journal of Knowledge Management, 5(4), pp. 27-53, 2007.

[13] P. P. Tallon. "Value chain linkages and the spillover effects of strategic information technology alignment: A process-level view". Journal of Management Information Systems, vol. 28, no.3, pp. 9-44, 2011.

[14] D. Avison, J. Jones, P. Powell, \& D. Wilson. "Using a validating the strategic alignment model". Journal of strategic information System, vol.13, pp. 223-246, 2004.

[15] D. Q. Chen, M. Mocker, D. S Preston, \& A. Teubner. "Information systems strategy: reconceptualization, measurement, and implications". MIS Quarterly, vol. 34, no.2, pp. 233-259, 2010.

[16] R. D. Galliers. "Further developments in information systems strategising: unpacking the concept". In: Galliers, R. D., Currie, W.L. (Eds.), The Oxford Handbook of Information Systems: Critical Perspectives and New Directions. Oxford University Press, Oxford, pp. 329-345, 2011.

[17] D. Hunger \& T. Wheelen. Strategic Management. USA: Addison-Wesley Longman Inc. 1998
[18] D.J. Teece, G. Pisano, \& A. Shuen. "Dynamic capabilities and strategic management". Strategic Management Journal, vol. 18, no.7, pp. 509-533, 1997.

[19] P. Rose \& S. Y Hudgins. Bank Management \& Financial Services. International Edition, New York: The McGrawHill Companies, Inc., 2008.

[20] J. H. Lingle \& W.A. Schiemann. "From balanced scorecard to strategic gauges: Is measurement worth it?" Management Review, vol. 85, no.3, pp. 56-61, 1996.

[21] R. Simmons. Performance Measurement and Control Systems for Implementing Strategy. New Jersey: Prentice Hall, 2000

[22] A. Neely, J. F. Mills, M. J. Gregory, \& K. W. Platts. "Performance measurement system design - a literature review and research agenda". International Journal of Operations \& Production Management, vol. 15, no.4, pp. 80-116, 1995.

[23] R. S Kaplan \& D. P. Norton. "The Balanced ScorecardMeasures that Drive Performance". Harvard Business Review, vol. 70, no.1, pp. 71-79, 1992.

[24] A. Bhimani \& K. Langfield-Smith. "Structure, formality and the importance of financial and non-financial information in strategy development and implementation". Management Accounting Research, vol. 18, no.1, pp. 331, 2007.

[25] A. Dossi \& L Patelli. "You Learn from What You Measure: Financial and Non-Financial Performance Measures in Multinational Companies". Long Range Planning, vol. 43, pp. 498-526, 2010.

[26] S. Gowrinathan. "Valuable Technologies to Make Bank Branches More Effective". Finacle, Infosys Ltd. 2011.

[27] A. Kanayi. "Building Tomorrow's Enterprise: The role of technology in building sustainable banking". Finacle, Infosys Ltd. 2012.

[28] OECD. Oslo Manual: Proposed Guidelines for Collecting and Interpreting Technological Innovation Data. Paris, 3rd Edition. 2005.

[29] OECD. The OECD Innovation Strategy: Getting A Head Start on Tomorrow. Executive Summary. Paris, 2010.

[30] F. Damanpou. "An Integration of Research Findings of Effects of Firm Size and Market Competition on Product and Process Innovations". British Journal of Management, vol. 21, no. 4, pp. 996-1010, 2010.

[31] A. Schumpeter. The Theory of Economic Development. Cambridge, MA: Harvard University Press. 1934

[32] A. Parasuraman. "Service productivity, quality and innovation: Implications for service-design practice and research". International Journal of Quality and Service Sciences, vol. 2, pp. 277-286, 2010.

[33] K. Grigoriou \& F. T. Rothaermel. "Structural microfoundations of innovation: The role of relational stars". Journal of Management, vol. 40, pp. 586-615, 2014

[34] Ghana Banking Survey. PricewaterhouseCoopers and Ghana Association of Bankers. Sustaining Growth: Challenges and Opportunities. Available Online: http://www.pwc.com/en_gh/gh/pdf/ghana-bankingsurvey-2011.pdf, 2011. Date accessed: 10th May, 2016.

[35] A. N. Berger \& A.A. Dick. "Entry into banking markets and the first-mover advantage". The Journal of Money, Credit and Banking, vol. 39, no.4, pp. 775-807, 2006.

[36] F. Damanpour and M. Schneider. "Phases of the adoption of innovation in organizations: effects of environment, organization and top managers". British Journal of Management, vol. 17, no.3, 215-236, 2006.

[37] R. J. Calantone, S. T. Cavusgil, \& Y. Zhao. "Learning Orientation, Firm Innovation Capability and Firm 
Performance". Industrial Marketing Management, 31(6), 515-524, 2002.

[38] F. Damanpour, R. M. Walker, \& C. N. Avellaneda. "Combinative effects of innovation types and organizational performance: A longitudinal study of service organizations". Journal of Management Studies, vol. 46, no.4, 650-675, 2009.

[39] J. C. Mahlich. "Patents and performance in the Japanese pharmaceutical industry: an institution- based view". Asia Pacific Journal of Management, vol. 27, no.1, pp. 99-113, 2010.

[40] J. Singh. "Distributed R\&D, cross-regional knowledge integration and quality of innovative output". Research Policy, vol. 37, pp. 77-96, 2008.

[41] J. Tidd, J. R. Bessant, \& K. Pavitt. Managing innovation: Integrating technological, market and organizational change. New York: John Wiley \& Sons Inc. 2005.

[42] S. B. Choi \& S. H. Lee. "Innovation and financial performance in emerging countries: an empirical analysis of Korean and Chinese firms". Academy of Management Annual Meeting Proceedings, pp. 1-6, 2008.

[43] J. Tung. "A study of product innovation on firm performance". International Journal of Organizational Innovation, vol. 4, no.3, pp. 84-97, 2012.

[44] J. Yang. "The knowledge management strategy and its effect on firm performance: a contingency analysis". International Journal of Production Economics, vol. 125, no. 2, pp. 215-223, 2010

[45] Z. Wang \& N. Wang. "Knowledge sharing, innovation and firm performance". Expert Systems with Applications, vol. 39, pp. 8899-8908, 2012

[46] F. Damanpour. "Organizational innovation: a metaanalysis of effects of determinants and moderators". Academy of Management Journal, vol. 34, no.3, pp. 555$590,1991$.

[47] R. Levine. "Financial development and economic growth: views and agenda". Journal of Economic Literature, vol. 35, no.2, pp. 688-726, 1997.

[48] A. Bharadwaj, O. El Sawy, P. Pavlou, \& N. Venkatraman. "Digital business strategy: toward a next generation of insights”. MIS Quarterly, vol. 37, no.2, pp. 471-482, 2013.

[49] T. R. Coltman, P. P Tallon, R. Sharma, \& M. Queiroz. "Strategic IT alignment: Twenty-five years on". Journal of Information Technology, vol. 30, pp. 91-100, 2015.

[50] F. J. Mata, W. L. Fuerst, \& J. B. Barney. "Information Technology and Sustained Competitive Advantage: A Resource-Based Analysis". MIS Quarterly, vol. 19, no.4, pp. 487-505, 1995.

[51] J.C. Henderson \& N. Venkatraman. "Strategic alignment: Leveraging information technology for transforming organisations". IBM Systems Journal, vol. 32, no.1, pp. 472-484, 1993.

[52] E. Turban, E. McLean, \& J. Wetherbe. Information technology for management: transforming business in the digital economy. 3rd Edition. New York: John Wiley. 2002.

[53] J. N. Luftman. "Assessing Business - IT Alignment Maturity". Communication of the association for information systems, vol. 4, no.14, December 2000.

[54] R. Sabherwal \& Y.E. Chan. "Alignment between business and IS strategies: a study of prospectors, analyzers and defenders". Information Systems Research, vol. 12, no. 1, pp. 11-33, 2001.

[55] R. Henderson \& W. Mitchell. "The interactions of organizational and competitive influences on strategy and performance". Strategic Management Journal, vol. 18, pp. $5-14,1997$.
[56] J. B. Barney. "Firm Resources and Sustained Competitive Advantage". Journal of Management, vol. 17, no.1, pp. 99-120, 1991.

[57] J. B. Barney \& W. S. Hesterly. Strategic management and competitive advantage: Concepts and Cases. 4th Edition. New Jersey: Pearson, 2012.

[58] R. D. Galliers. Reflections on Information Systems Strategizing, in C. Avgerou, C. Ciborra, and F. Land (Eds.) The Social Study of Information and Communication Technology: Innovation, Actors, and Contexts. UK, Oxford: Oxford University Press, pp. 231-262, 2004.

[59] R. Agarwal and V. Sambamurthy. "Principles and Models for Organizing the IT Function". MIS Quarterly Executive, vol. 1, no.1, 1-16, 2002.

[60] P. Weill. "Strategic investment in information technology: An empirical study". Information Age, vol. 12, no. 3, pp. 141-147, 1990.

[61] Z. Tang \& B. Walters. "The Interplay of Strategic Management and Information Technology" In M. Hunter (Ed.), Strategic Information Systems: Concepts, Methodologies, Tools, and Applications, pp. 29-41, 2010.

[62] D.W. Jorgenson \& K. Vu. "Information Technology and the World Growth Resurgence". German Economic Review, vol. 8, no.2, pp. 125-145, 2007.

[63] A.A. Aliyu \& R. Bin H.J. Tasmin. "The Impact of Information and Communication Technology on Banks Performance and Customer Service Delivery in the Banking Industry". International Journal of Latest Trends in Finance \& Economic Sciences, 2(1), 80-90, 2012.

[64] M. Broadbent \& P. Weill. "Improving business and information strategy alignment: Learning from the banking industry". IBM Systems Journal, vol. 32, no.1, $162-179,1993$.

[65] A. S. Bharadwaj. "A resource-based perspective on information technology capability and firm performance: an empirical investigation”. MIS Quarterly, vol. 24, no.1, pp. 169-196, 2000.

[66] M. Wade \& J. Hulland. "The resource-based view and information systems research: review, extension and suggestions for future research". MIS Quarterly, vol. 28, no. 1, pp. 107-142, 2004.

[67] D. S. Preston and E. Karahanna. "How to Develop a Shared Vision, The Key to IS Strategic Alignment". MIS Quarterly Executive, vol. 8, no.1, pp. 1-8, 2009b.

[68] H. Mintzberg. "The Strategy Concept I: Five Ps for Strategy". California Management Review, vol. 30, no.1, pp. 11-24, 1987.

[69] J. W. Ross, P. Weill, and D. C. Robertson. Enterprise Architecture As Strategy. Boston: Harvard Business School Press, 2006.

[70] E. Baldwin and M. Curley. Managing IT Innovation for Business Value: Practical Strategies for IT and Business Managers. CA: Santa Clara, Intel Press, 2007.

[71] G. Piccoli and B. Ives. "IT-Dependent Strategic Initiatives and Sustained Competitive Advantage: A Review and Synthesis of the Literature". MIS Quarterly, vol. 29, no.4, pp. 747-776, 2005.

[72] C. U. Ciborra. From Thinking to Tinkering. The Grassroots of IT and Strategy, in Strategic Information Systems: A European Perspective, Ciborra, C. U. and Jelassi, T. (eds.), Chichester, UK: John Wiley, pp. 3-24, 1994.

[73] R. D. Galliers. "Strategizing for agility: confronting information systems inflexibility" in dynamic environments. In: Desouza, K. (Ed.), Agile Information Systems. Butterworth-Heinemann, pp. 1-15, 2006.

[74] V. Sambamurthy, A. Bhardwaj, \& V. Grover. "Shaping 
agility through digital options: Reconceptualizing the role of information technology in contemporary Firms1". MIS Quarterly, vol. 27, no. 2, pp. 237-263, 2003.

[75] F. R. David. Strategic Management Concepts: A Competitive Advantage Approach. 14th Edition. Prentice Hall, 2012.

[76] D. J. Teece. "Business Models, Business Strategy and Innovation". Long Range Planning, vol. 43, 172-194, 2010.

[77] S. Rivard, L. Raymond, \& D. Verreault. "Resource-Based View and Competitive Strategy: An Intended Model of the Contribution of Information Technology to Firm Performance". Journal of Strategic Information Systems, 15 , pp. 29-50, 2006

[78] G. Bassellier \& I. Benbasat. "Business competence of information technology professionals: conceptual development and influence on IT-business partnerships". MIS Quarterly, vol. 28, no.4, pp. 394-673, 2004.

[79] M. Khosrowpour (Ed.). Cases on Information Technology and Business Process Reengineering. Hershey, PA: Idea Group Publishing, 2006.

[80] R. G. Fichman \& C. F. Kemerer. "The assimilation of software process innovations: an organizational learning perspective". Management Science, vol. 43, no.10, pp. 1345-1363, 1997.

[81] J. W. Ross, C. M. Beath, \& D. L. Goodhue. "Develop long-term competitiveness through IT assets". Sloan Management Review, vol. 38, no.1, pp. 31-42, 1996.

[82] E. B. Swanson. "Inside the IT Innovation Wave Machine," UCLA Anderson School of Management Information Systems Working Paper Series, pp. 1-10, 2010.

[83] I-L. Wu \& M-L. Chiu. "Organizational applications of IT innovation and firm's competitive performance: A resource-based view and the innovation diffusion approach". Journal of Engineering and Technology Management, vol. 35, no. 25, pp. 25-44, 2015.

[84] J. Benitez-Amado \& R.M Walczuch. "Information technology, the organizational capability of proactive corporate environmental strategy and firm performance: a resource-based analysis". European Journal of Information Systems, vol. 21, pp. 664-679, 2012.

[85] J. Peppard \& Ward. "Beyond strategic information systems: towards an IS capability". Journal of Strategic Information Systems, vol. 13, pp. 167-194, 2004.

[86] N.-C. Chen. "Cloud Computing as an Innovation: Perception, Attitude, and Adoption". International. Journal of Information Management, vol. 32, no.6, pp. 533-540, 2012.

[87] T. Felin \& W. S Hesterly. "The knowledge based view, nested heterogeneity, and new value creation: Philosophical considerations on the locus of knowledge". Academy of Management Review, vol.32, pp. 195-218, 2007.

[88] M. Gloet \& M. Terziovski. "Exploring the relationship between knowledge management practices and innovation performance". Journal of Manufacturing Technology Management, vol. 15, no.5, pp. 402-409, 2004.

[89] M. M. Crossan \& I. Berdrow. "Organizational Learning and Strategic Renewal". Strategic Management Journal, vol. 24 , pp. 1087-1105, 2003.

[90] G. S Kearns and A. L. Lederer. "A resource-based view of strategic IT alignment: how knowledge sharing creates competitive advantage". Decision Sciences, vol. 34, no.1, pp. 1-29, 2003.

[91] D. Sledgianowski \& J. Luftman. "IT-Business Strategic Alignment Maturity: A Case Study". Journal of Cases on
Information Technology, vol. 7, no.2, pp. 102-120, 2005.

[92] J.N. Luftman, R. Papp \& T. Brier. "Enablers and inhibitors of business-IT alignment". Communications of the AIS, vol. 1, no.11, pp. 1-32, 1999.

[93] S. L. Goldman, R. N. Nagel, \& K. Preiss. Agile Competitors and Virtual Organizations: Strategies for Enriching the Customer. New York: Van Nostrand Reinhold, 1995.

[94] C. C. Liao, H. Y. Wang, S. H. Chuang, M. L. Shih, \& C. C. Liu. "Enhancing knowledge management for R\&D innovation and firm performance: An integrative view". African Journal of Business Management, vol. 4, no.14, pp. 3026-3038, 2010

[95] D. Lavie. "The case of a process theory of resource accumulation and deployment". Strategic Organization, vol. 10, no.3, pp. 316-323, 2012.

[96] B-A. Lundvall \& P. Nielsen. "Knowledge management and innovation performance". International Journal of Manpower, vol. 28, no.3/4, pp. 207-223, 2007.

[97] N. Carbonara. "Information and communication technology and geographical clusters, opportunities and spread". Technovation, vol. 25, no.3, pp. 213-222, 2005.

[98] D. Jiménez-Jiménez \& R. Sanz-Valle. "Innovation, organizational learning, and performance". Journal of Business Research, vol. 64, pp. 408-417, 2011.

[99] R. Amit \& P. Schoemaker. "Strategic assets and organizational rent”. Strategic Management Journal, vol. 14, no. 1, pp. 33-46, 1993.

[100] B. Wernerfelt. "A resource-based view of the firm". Strategic Management Journal, vol. 5, pp. 171-180, 1984

[101] E. T. Penrose. The Theory of Growth of the Firm. New York: Wiley 1959.

[102] R. M. Grant. "Prospering in dynamically competitive environments: organizational capability as knowledge integration". Organization Science, vol. 7, pp. 375-387, 1996 .

[103] P. Pavlou \& O. El-Sawy. "The "third hand": IT-enabled competitive advantage in turbulence through improvisational capabilities". Information Systems Research, vol. 21, pp. 443-471, 2010.

[104] G. Walsham. "Doing interpretive research". European Journal of Information Systems, vol. 15, pp. 320-330, 2006.

[105] J. W. Creswell. Qualitative inquiry and research design: Choosing among five approaches. 2nd Edition. CA: Thousand Oaks, Sage, 2007.

[106] J. W. Creswell. Qualitative Inquiry and research design: Choosing among five traditions. CA: Thousand Oaks, Sage, 1998.

[107] P. Darke, G. Shanks, and M. Broadbent. "Successfully completing case study research: Combining rigour, relevance and pragmatism". Information Systems Journal, vol. 8, no. 4, pp. 273-289, 1998.

[108] B. G. Glaser \& A. L. Strauss. The discovery of grounded theory: Strategies for qualitative research. New York: Aldine, 1967.

[109] A. Strauss \& J. Corbin. Basics of qualitative research: Grounded theory procedures and techniques. Newbury Park, CA: Sage, 1990.

[110] K. Charmaz. Constructing grounded theory: A practical guide through qualitative analysis. London: Sage, 2006.

[111] R. Matavire \& I. Brown. "Profiling Grounded Theory Approaches in Information Systems Research". European Journal of Information Systems, vol. 22, pp. 119-129, 2013.

[112] P. P. Tallon and A. Pinsonneault. "Competing Perspectives on the Link between Strategic Information 
Technology Alignment and Organizational Agility: Insights from a mediation model". MIS Quarterly, vol. 35, no.2, pp. 463-486, 2011.

[113] J. Gerdin and J. Greve. "Forms of Contingency Fit in Management Accounting Research - A critical review". Accounting, Organizations and Society, vol. 29, no.3, pp. 303-326, 2004.

[114] J.R. Edwards. "The Study of Congruence in Organizational Behavior Research: Critique and a proposed alternative". Organizational Behavior and Human Decision Processes, vol. 58, no.1, pp. 51-100, 1994.

[115] P.P. Tallon, K.L. Kraemer, \& V. Gurbaxani. "Executives' perceptions of the business value of information technology: a process-oriented approach". Journal of Management Information Systems, vol. 16, no.4, pp. 145$173,2000$.

[116] J. E. Gerow, J. B. Thatcher, and V. Grover. "Six Types of IT-Business Strategic Alignment: An investigation of the constructs and their measurement”. European Journal of Information Systems, vol. 24, no.3, pp. 1-27, 2014.

[117] B.J. Jaworski \& A.K. Kohli. "Market-orientation: antecedents and consequences". Journal of Marketing, vol. 57, pp. 53-70, 1993.

[118] Y.E Spanos \& S. Lioukas. "An examination into the causal logic of rent generation: contrasting Porter's competitive strategy framework and the resource-based perspective". Strategic Management Journal, vol. 22, no.10, pp. 907-934, 2001.

[119] J. Darroch. "Knowledge management, innovation and firm performance". Journal of Knowledge Management, vol. 9, no.3, pp. 101-115, 2005.

[120] D. J. Ortinau, J. F. Hair, \& R. P. Bush. Marketing Research: Within a Changing Information Environment. New York: McGraw-Hill/Irwin, 2003.

[121] A. J. Onwuegbuzie, N. L. Leech, \& K. M. T. Collins. Toward a new era for conducting mixed analyses: The role of quantitative dominant and qualitative dominant crossover mixed analyses. In M. Williams \& W. P. Vogt (Eds.), The Sage handbook of innovation in social research methods. Thousand Oaks, CA: Sage, 2011, pp. $353-384$

[122] A. J. Onwuegbuzie, R. B. Johnson, \& K. M. T. Collins. "A call for mixed analysis: A philosophical framework for combining qualitative and quantitative". International Journal of Multiple Research Methods, vol. 3, no.2, pp. 114-139, 2009.

[123] C.W. Roberts. "A conceptual framework for quantitative text analysis: on joining probabilities and substantive inferences about texts". Quality \& Quantity, vol. 34, pp. 259-274, 2000.

[124] P. Zapata-Sepúlveda, F. López-Sánchez, and M. C. Sánchez-Gómez. "Content analysis research method with NVivo-6 software in a $\mathrm{PhD}$ thesis: an approach to the long-term psychological effects on Chilean ex-prisoners survivors of experiences of torture and imprisonment". Quality and Quantity, vol. 46, no. 1, pp. 379-390, 2011

[125] S. Pan, K. Chon, \& H. Song. "Visualizing Tourism Trends: A Combination of ATLAS.ti and BiPlot". Journal of Travel Research, vol. 46, no.3, pp. 339-348, 2008.

[126] M. Bendixen. "A practical guide to the use of correspondence analysis in marketing research". Marketing Research On-Line, vol. 1, no.1, pp. 16-36, 1996.

[127] J. F. Hair, W. C. Black, B. Babin, \& R. Anderson.
Multivariate data analysis. 7th Edition. Upper Saddle River, NJ: Prentice-Hall, 2010.

[128] A. Agresti. Categorical data analysis. $2^{\text {nd }}$ Edition. Hoboken: John Wiley \& Sons, 2002

[129] M. J. Greenacre. Correspondence analysis in practice. New York: Academic Press, 1993.

[130] J. C. Ryan \& S. A. A. Tipu. "Leadership effects on innovation propensity: A two-factor full range leadership mode". Journal of Business Research, vol. 66, pp. 21162129, 2013.

[131] D. F. Feeny \& L.P. Willcocks. "Core IS capabilities for exploiting information technology". Sloan Management Review, vol. 39, no.3, pp. 9-21, 1998.

[132] M. Beer \& R. Eisentat. "The Six Silent Killers of Strategy Implementation and Learning". Sloan Management Review, vol. 41, no.4, pp. 29-41, 2000.

[133] Y. E. Chan \& S. L. Huff. "Investigating Information Systems Strategic Alignment". Paper presented at the Proceedings of the Fourteenth International Conference on Information Systems, Orlando, Florida. 1993.

[134] P. P. Tallon \& K. L. Kraemer. Investigating the Relationship between Strategic Alignment and Business Value. Hershy, PA: Idea Publications, pp. 1-22, 2003.

[135] R. M. Walker. "Innovation and organizational performance: evidence and a research agenda". Working Paper, No. 002, Advanced Institute of Management Research. 2004.

[136] J. N. Luftman, R. Papp, \& T. Brier. "Enablers and inhibitors of business-IT alignment". Communications of the AIS, vol. 1, no. 10, pp. 1-32,1999.

[137] J. P. MacDuffie. "Human resource bundles and manufacturing performance: organizational logic and flexible production systems in the world auto industry". Industrial and Labor Relations Review, vol. 48, no.2, pp. 197-221, 1995.

[138] A. N. H. Zaied. “An Integrated Knowledge Management Capabilities Framework for Assessing Organizational Performance". I. J. Information Technology and Computer Science, Vol 2, pp 1-10, 2012.

\section{Authors' Profiles}

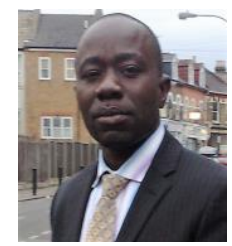

Asare Yaw Obeng is a $\mathrm{PhD}$ student of Information Systems at the University of South Africa. He is currently a lecturer at Kumasi Polytechnic, Ghana, Computer Science Department. His research interests include the role of IT in technological innovation, IS/business alignment, and information systems strategy. He holds an M.Sc. in Information Systems from the University of North West, USA.

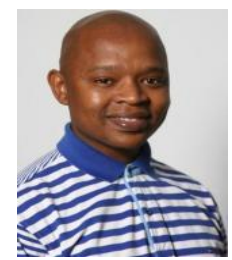

Prof Peter L Mkhize (PhD) is an Associate Professor of Software Engineering, School of Computing at the University of South Africa (UNISA). Peter currently serves as the group leader of software engineering. His research has been presented at several international conferences including ICMLG and Intellectual Capital, Knowledge Management and Organizational Learning. 
How to cite this paper: Asare Yaw Obeng, Peter L Mkhize,"Impact of IS Strategy and Technological Innovation Strategic Alignment on Firm Performance", International Journal of Information Technology and Computer Science(IJITCS), Vol.9, No.8, pp.68-84, 2017. DOI: 10.5815/ijitcs.2017.08.08 